\title{
Internal Bleaching of a Non vital Anterior Tooth in Patient with Postural Hypotension
}

\author{
(Pemutihan Internal Gigi Anterior Non vital pada Pasien dengan Hipotensi Postural) \\ Ramadhani Putri Salicha, Kun Ismiyatin, Paramita Tanjung Sari, Olivia Vivian Widjaja, Ria Puspita Sari \\ Department of Conservative Dentistry, \\ Faculty of Dental Medicine, Universitas Airlangga, \\ Surabaya- Indonesia \\ Email: kun-is@fkg.unair.ac.id
}

\begin{abstract}
Postural hypotension is a form of low blood pressure, characterized a $20 \mathrm{mmHg}$ decrease in systolic blood pressure or a $10 \mathrm{mmHg}$ drop in diastolic blood pressure when rising from a sitting or lying position. This can cause syncope. A patient who comes to a dentist with postural hypotension may be a tough case. A 48-year-old woman arrived with postural hypotension and felt dissatisfied with the discolored and unsightly condition of her upper central incisor. This clinical case shows a management of postural hypotension patient in internal bleaching technique on non-vital teeth using $35 \%$ hydrogen peroxide. This therapy is simple, safety and adequate for patients who has postural hypotension with satisfactory results.
\end{abstract}

Keywords: Tooth bleaching, Tooth discoloration, Hypotension, Orthostatic

\begin{abstract}
Abstrak
Postural hipotensi adalah suatu bentuk tekanan darah rendah yang ditandai dengan penurunan tekanan darah sistolik sebesar $20 \mathrm{mmHg}$ atau penurunan tekanan darah diastolik sebesar $10 \mathrm{mmHg}$ saat bangkit dari posisi duduk atau berbaring. Hal ini dapat menyebabkan sinkop. Seorang pasien yang datang ke dokter gigi dengan memiliki postural hipotensi mungkin merupakan kasus yang cukup sulit. Seorang wanita 48 tahun dengan postural hypotension datang ke dokter gigi karena merasa tidak puas dengan kondisi gigi seri sentral atasnya yang berubah warna dan tidak sedap dipandang. Kasus ini menunjukkan penatalaksanaan pasien dengan postural postural dalam perawatan internal bleaching pada gigi non vital menggunakan 35\% hidrogen peroksida. Terapi ini merupakan terapi yang sederhana, aman dan memadai untuk pasien yang memiliki riwayat postural hipotensi, tentu saja dengan hasil yang memuaskan.
\end{abstract}

Kata Kunci: Bleaching gigi, Diskolorasi gigi, Hipotensi, Ortostatik

\section{INTRODUCTION}

Postural hypotension, also known as orthostatic hypotension, is characterized by an excessive drop in systolic blood pressure (> $20 \mathrm{~mm} \mathrm{Hg}$ ) after lying down or sitting then standing up. This causes in hypoperfusion cerebral and symptoms (e.g., dizziness, light-headedness and near syncope). Postural hypotension in patients with syncope was observed in most cases (89 per cent) within 2 minutes of standing. This can cause syncope. A patient who comes to a dentist with postural hypotension may be a tough case. ${ }^{1,3}$.

Tooth discolorations divide to intrinsic, extrinsic, or a mixture of all the above. For example, pulp necrosis may cause tooth discoloration due to bacterial substance, mechanical or chemical irritation of the pulp, then the product can enter the dentinal tubules.
Dental bleaching is a minimally invasive conservative solution for aesthetic problems, without any destruction of tooth structure. ${ }^{2,5}$

There are many protocols for bleaching non vital tooth such as internal and external bleaching. Internal bleaching as known as intrinsic bleaching, is the procedure used to position bleaching agents within the dental pulp in close contact with dentin. Internal bleaching is a treatment option that can be given in cases with discoloration of teeth that have been done endodontic treatment. Internal bleaching on non-vital teeth is recommended because of economical, predictable, quick with good esthetic results. This treatment is also quite safe and has a mild risk. Over the past decade, the demand of minimal invasive treatment is increasing, such as whitening 
procedure. These materials rely not only from the aspects of light propagation, but also about the color of the teeth that are being repaired. This case report reported a case about the treatment of non-vital discoloration tooth with postural hypotension. ${ }^{3,4,5,6}$

\section{CASE REPORT}

A 48-year-old woman arrived in Conservative clinic in the Dental Hospital of Airlangga University. Patient complained of discolored and different color of her upper central incisor (Figure 1). She had a trauma before when she woke up in a rush a month ago. She was diagnosed with postural hypotension by her internist. And she was not under any medications.

\section{CASE MANAGEMENT}

From Clinical and radiographic, A diagnosis maxillary right central incisor was non vital tooth (pulp necrose), based on a vitality test using an electric pulp tester.

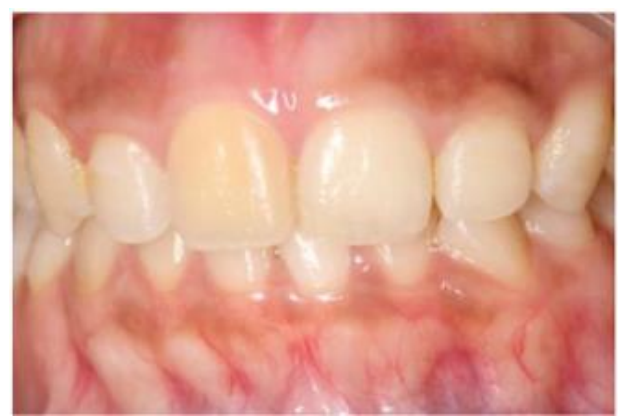

Figure 1. Discolored maxillary right central incisor tooth

The blood pressure of the patient was 90/60 and the heart rate was 80 beats / minute in standing posture. When tested in a seated posture, the patient's blood pressure was 100/80 and his heart rate was 90 beats / minute. Respiratory frequency was 16 breaths per minute. Root canal treatment was performed on tooth 11. First, the teeth were isolated using rubber dam, then access cavity preparation was performed. The canal was negotiated to the apex using \#10 K-files. An apex locator was used to assess the working length (Figure 2) and it was radiographically confirmed (Figure 3 ). An apical glide path was established using a Proglider file (Dentsply).

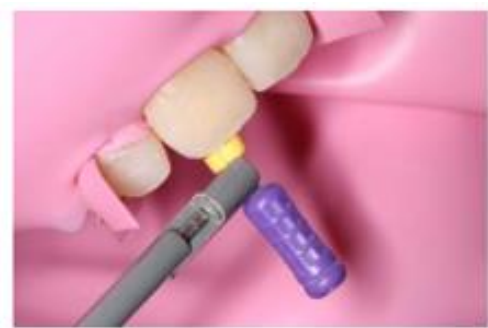

Figure 2. Working Length determination

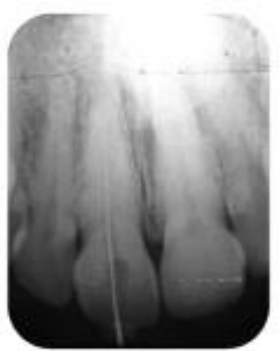

Figure 3. Radiographically confirmed working length

The biomechanical preparation of the root canal was performed with rotary NiTi files until X2 file Protaper Next (Dentsply), using the crown-down pressure less technique (Figure 4). The canal was activated by a sonic activator (Endo Activator, Dentsply) with 5.25 percent sodium hypochlorite (NaOCl)irrigation between the instrumentations (Figure 5). Trial gutta point was performed, and radiographically confirmed (Figure 6; Figure 7). Finally, the root canal was irrigated using $\mathrm{NaOCl} 5,25 \%$, EDTA $17 \%$, and water saline. Then, using the paper point, the canal dried. Next, the canal was obtured using single cone technique and resin-based sealer. Obturation was confirmed radiographically and temporary fillings were placed (Figure 8).

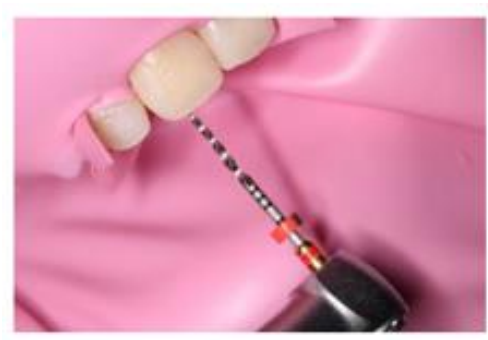

Figure 4. Biomechanical preparation

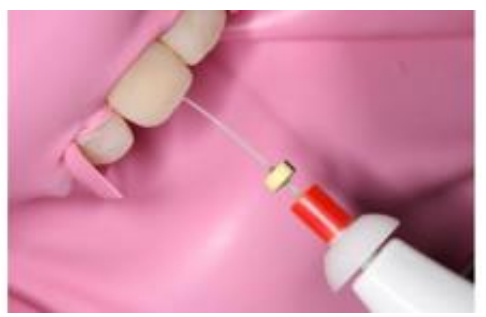

Figure 5. Irrigation activation 


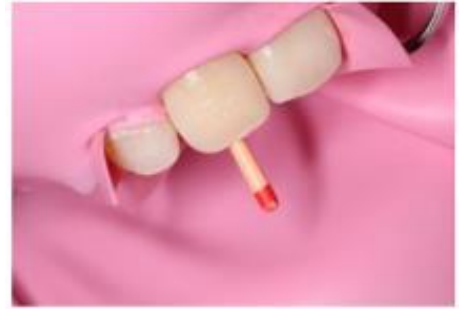

Figure 6. Trial gutta point

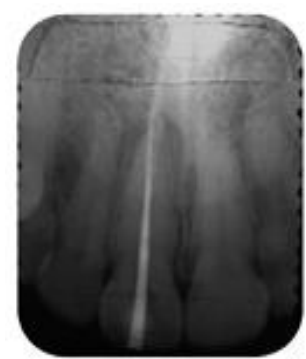

Figure 7. Trial gutta percha radiographically confirmed

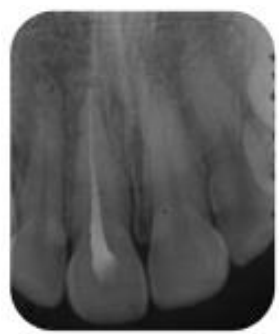

Figure 8. Obturation radiographically confirmed

At the 1-week follow up, the extraoral and intraoral revealed no symptoms or signs. The color of the tooth (Figure 9) was measured under regular daylight with a Vita 3D shade guide (4M2). The tooth was isolated using a rubber dam and removed the temporary fillings. Then, reduction $2 \mathrm{~mm}$ of gutta percha in above the cemento-enamel junction (CEJ) (Figure 10), and Glass Ionomer Cement as a cervical barrier was applied which used ski slope and bobsled tunnel appearance design, confirmed radiographically (Figure 11). Bleaching agents (35\% Hydrogen Peroxide) applied into the pulp chamber and light cured temporary fillings were placed (Figure 12). Patient was asked to control in 3 days if the discolored tooth had similar color with adjacent tooth.

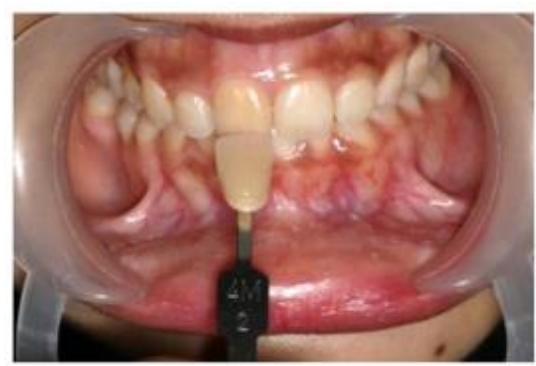

Figure 9. Shade guide determination

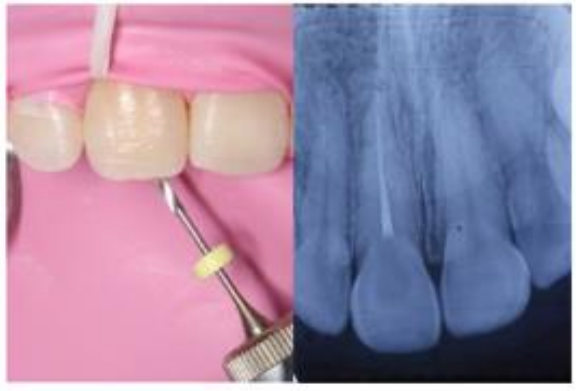

Figure 10. Gutta percha removal

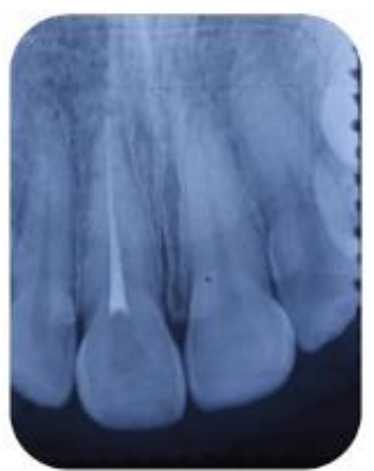

Figure 11. Cervical barrier placement.

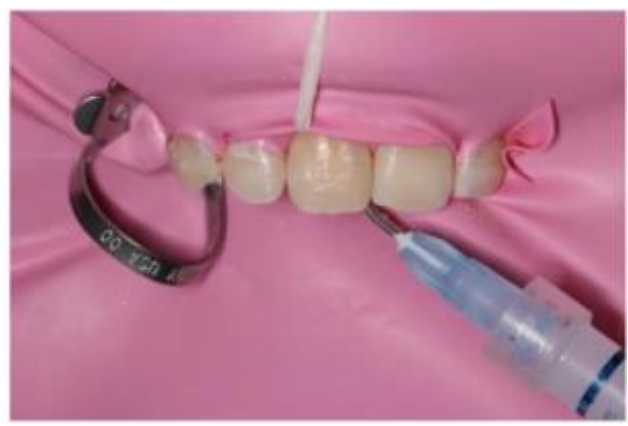

Figure 12. Application of bleaching agent

At the 3-days follow up, the discolored tooth had similar color to the adjacent tooth, checked with Vita shade guide 2M2 (Figure 13). The tooth was isolated using rubber dam, and temporary fillings were removed. The saline was rinsed and dried in the pulp chamber, calcium hydroxide was added, and placed in the dental chamber for a week until final restoration.

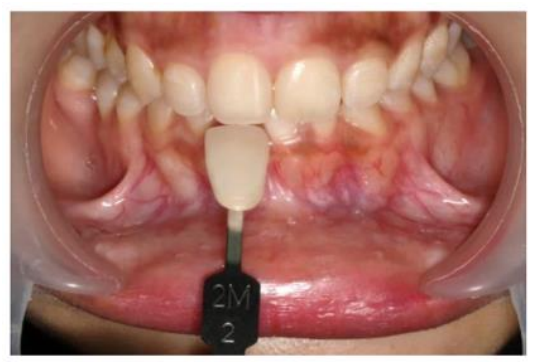

Figure 13. Shades taking after internal bleachin 
At the 1-week follow up, the extraoral and intraoral revealed no symptoms or signs. Composite color determination was performed. The tooth was isolated using a rubber dam, 37\% phosphoric acid was performed for $30 \mathrm{sec}$ (Figure 14). Then, rinsed with water and dried. Bonding was applied in total etch system and light cured (Figure 15). Permanent restoration was applied using light cured composite (Figure 16; Figure 17). Finishing and contouring done by using soflex disc and polishing done by using eve diacomp twist (Figure 18). During the treatment, patient did not complain about dizziness and limpness.

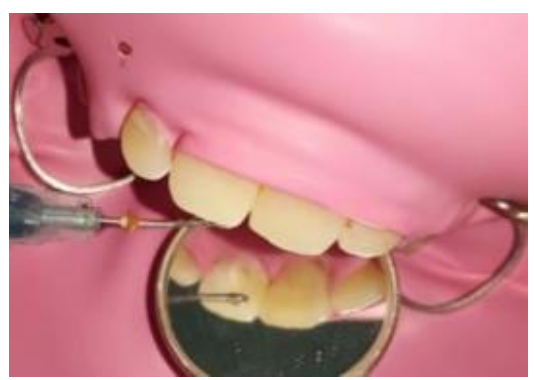

Figure 14. Etch application.

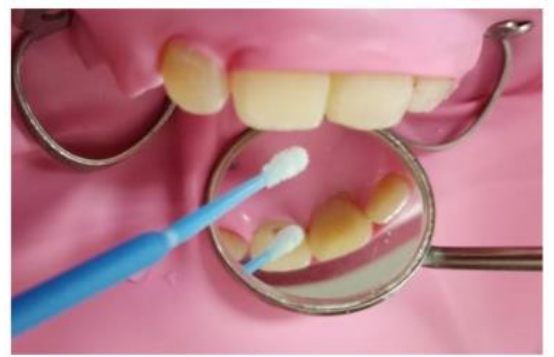

Figure 15. Bonding application.

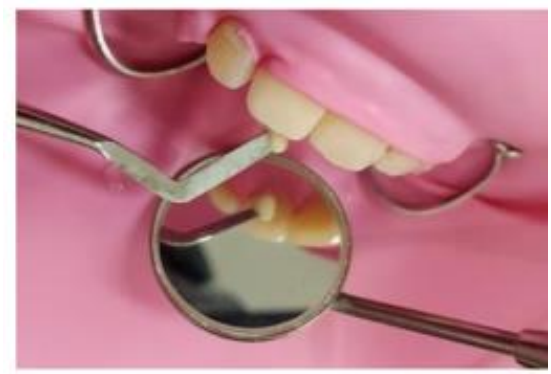

Figure 16. Composite application.

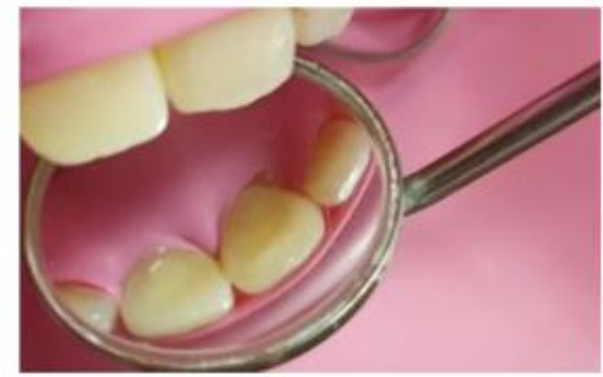

Figure 17. Permanent restoration
The patient was called to review the therapy result after 3 months: the restoration was in great condition; no fractured, cracked, no discoloration was observed; and the supporting tissues was good without inflammation (Figure 19). Patient has satisfied with the result.

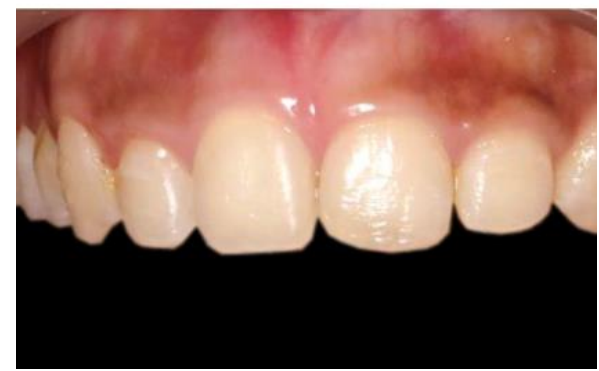

Figure 18. Post-Operative.

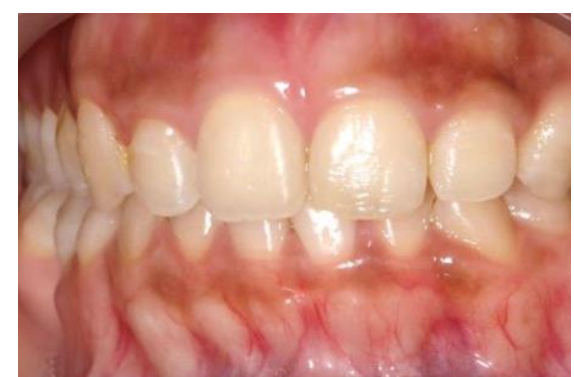

Figure 19. 3 months after permanent restoration

\section{DISCUSSION}

Some systemic disease can cause a sudden fell to patient, one of them is a patient with postural hypotension. Lightheadedness or dizziness that begins only a few seconds on standing are indicative of postural hypotension; vision suddenly dims or blurs. Dentists must be more careful in identifying at-risk patients. The operator better makes appointments 30 to 60 minutes after the ingestion of meals and medications when the patient is declared have postural hypotension to get dental treatment ${ }^{7,12}$.

In patients with postural hypotension, dental therapy with a long chair period can increase the risk of syncope. So, in sitting, semi-supine, and supine positions, it is important to examine the heart rate of the patient. A clinician can proceed the treatment if the patient does not complain of dizziness, limpness, and the patient's heart rate does not change. A clinician needs to change the dental unit position slowly, by changing 2 to 3 times with 1-minute intervals, so the patient can adapt in the new position. ${ }^{1,8}$

The size of the existing tooth structure, the accuracy of root canal treatment and the condition of the periodontal tissues should be noted by the operator, then they can choose the material and procedure of bleaching treatment. All the required criteria for the indication of internal bleaching, which 
is good quality of endodontic treatment, a significant amount of tooth structure and intact root internal walls are stated by the tooth in this case. The biological protection related to the dosage of the substance and the time of use should be considered by whitening techniques; and therapeutic safety related to the harmful effects that might arise, such as soft tissue inflammation, improvements in the strength of the enamel and permeability of the dentin, should also be considered. ${ }^{2,5,9}$

There are many other options for treatment the discoloration teeth like restorative indirect such as crown or veneers, but this kind of treatment make an invasive technique. When we prioritize the minimally invasive, internal bleaching can offers simple conservative approach without damaging tooth structure. The process of indirect bleaching begins when its chemical process touches the tooth's surface $^{6,10,11}$.

Root filling or gutta percha should be lowered by 1-2 mm under the cement enamel junction (CEJ). Pulp chamber must be washed of the debris and traces of the substance of endodontic products or pollutants since the effectiveness of the bleaching agent can be adversely affected. This cervical barrier prevents the diffusion from the pulpal chamber of bleaching agents to the apical foramen, the cervical resorption formed in the pulp chamber by the bleaching agent. It is crucial to get a good procedure. As the barrier material, glass ionomer cement, a coating of around 2-3 mm, was used. The shape of the barrier was kept as 'bobsled tunnel' when viewed from facial aspect. The advantages of this shape can block all the dentinal tubules which run from pulp chamber to external tooth surface apical to the level of epithelial attachment so that the bleaching agent stays within the cavity and hence prevents external root resorption ${ }^{4,8,11}$.

Bleaching agents which contains oxidation agent are hydrogen peroxide, chlorin or natrium hypochlorite. In this case we used hydrogen peroxide, a strong oxidation effect, is easily used and changed in 3-7 days for maximal oxidation. The intensity of discoloration affects the bleaching time. In this case, only once application needed to get the similar color to the adjacent tooth. The main whitening agent employed is hydrogen peroxide $(\mathrm{H} 2 \mathrm{O} 2)$. It is a thermally unstable free radical with a low molecular weight which, by diffusion, penetrates the enamel and dentin. It is established that hydrogen peroxide influences both organic as well as inorganic part of dentin. Destruction of organic component is mainly due to the oxidizing nature of hydrogen peroxide, whereas the inorganic portion is damaged due to acidity. Complex molecules of organic pigments in the tissues are broken down into simpler hydrophilic molecules through an oxidation reduction reaction by the action of per hydroxyl ions resulting from the degradation of $\mathrm{H}_{2} \mathrm{O}_{2}$. When in contact with water, these simpler compounds are readily separated from the dental tissue, which can have the whitening effect. Biocompatibility of the bleaching agent is important to speed up result. ${ }^{4,10,13,15}$

Final restoration in this case is resin composite. Before the application of resin composite, the bleaching was rinsed, and the pulp chamber filled with calcium hydroxide. Patricia et al, said that the bleaching agents improved the $\mathrm{pH}$ of the external medium at 7 days and the calcium hydroxide could increase the external medium $\mathrm{pH}$ and was useful for pH alkalinization after intracoronal bleaching. ${ }^{7,14}$

When all the treatment has been done, the operator should not let the patient wake up on his own for precaution if limpness and dizziness suddenly occur on this patient. This is important when the patient get a treatment which take more time such as endodontic and internal bleaching treatment. ${ }^{7,8}$

In Conclusion, this case report shows the adequate treatment of a discolored non vital tooth in patient with postural hypotension using $35 \%$ hydrogen peroxide as bleaching agent. Internal bleaching offers simple conservative approach in whitening discolored tooth minimally invasive without damaging tooth structure, low-cost treatment, and good aesthetic result. Cervical barrier should be used in this treatment to avoid other problems. Heart rate and position of the patient with postural hypotension are a concern in the treatment implementation.

\section{REFERENCES}

1. Peeters SY, Hoek AE, Mollink SM, Huff JS. Syncope: risk stratification and clinical decision making. Emerg Med Pract 2014; 16(4): 1-2

2. Rotstein I. Intracoronal bleaching of nonvital teeth. In: Greenwall L. eds. Tooth Whitening Techniques. $2^{\text {nd }}$ ed. London: CRC Press, 2017: 143-162.

3. Patil AG, Hiremath V, Kumar RS, Sheetal A, Nagaral S. Bleaching of a non vital anterior tooth to re-

move the intrinsic discoloration. J Nat Sci Biol Med 2014; 5(2): 476-479.

4. Pandey SH, Patni PM, Jain P, Chaturvedi A. Management of Intrinsic Discoloration Using Walking Bleach Technique in Maxillary Central Incisors. Clujul Medical. 2018. 91(2):229-33.

5. Izidioro ACSA, Martins GC, Higashi C, Grande CZ, Tay LY, Gomes JC, et al. Combined technique for bleaching non vital teeth with 6-months clinical 
follow up: case report. Int J Oral Dent Health. 2015; 1(2): $1-4$

6. Awadhiya S. Narang A. Agarwai M, Jain M. Non vital bleaching: A case Series on Whitening Procedure for Discolored Endodontically Treated Teeth. IJOPRD 2018; 8(1): 28-31.

7. Shibao C, Lipsitz LA, Biaggioni I. ASH position paper: evaluation and treatment of orthostatic hypotension. J Clin Hypertens 2013; 15(3): 147-53.

8. Malamed S. Medical Emergencies in the Dental Office. $7^{\text {th }}$ ed. St. Louis: Elsevier, 2015: 153-160.

9. Presoto CD, Bortolatto JF, Carvalho PPF, Trevisan TC, Floros MC, Oliveira OB. New parameter for inoffice dental bleaching. Case Rep Dent 2016; 2016: $1-5$

10. Meraji N, Ahmadi E. The effect of bleaching agents on the microstucture and surface microhardness of three calcium silicate-based barrier materials. IEJ 2020; 15(1): 23-30

11. Tanmi FH, Hossain M, Howlader MR, Abdin J, Alam S, Moral MAA. Esthetic correction of calcified tooth discoloration by walking bleach technique. BSMMU J 2017; 10: 234-39
12. Moghadam N, Abdollahi AA, Fakhim HA, Borna Z. In vitro sealing properties of calcium-enriched mixture and mineral trioxide aggregate orifice barriers during intra-coronal bleaching. IEJ 2017; 12(2): 231-35

13. Rokaya ME, Beshr K, Mahram AH, Pedir SS, Baroudi K. Evaluation of extraradicular diffusion of hydrogen peroxide during intracoronal bleaching using different bleaching agents. Int J dent 2015; 2015: $1-7$

14. Sa PM, Jeronymo RD, Yui KC, Silva EG, Huhtala MF, Torres CR, Gomes AP. Effect of calcium hydroxide on $\mathrm{pH}$ changes of the external medium after intracoronal bleaching. J Contemp Dent 2011; 12(3): 158-63.

15. Coelho AS, Garrido L, Mota M, Marto CM, et al. Non vital tooth bleaching techniques: A systematic review. Coatings 2020; 10(61): 1-10 